\title{
Incidence of acute bee paralysis virus, black queen cell virus, chronic bee paralysis virus, deformed wing virus, Kashmir bee virus and sacbrood virus in honey bees (Apis mellifera) in Denmark*
}

\author{
Steen Lykke NiElSEN, Mogens Nicolaisen, Per KRYGER \\ University of Aarhus, Faculty of Agricultural Sciences, Department of Integrated Pest Management, \\ 4200 Slagelse, Denmark
}

Received 31 July 2007 - Revised 13 December 2007 - Accepted 13 December 2007

\begin{abstract}
Samples of adult honey bees from apiaries with unusually high winter mortality and brood from hives with symptoms of disease were tested for presence of acute bee paralysis virus (ABPV), black queen cell virus (BQCV), chronic bee paralysis virus (CBPV), deformed wing virus (DWV), Kashmir bee virus $(\mathrm{KBV})$ and sacbrood virus (SBV) by RT-PCR. All six viruses were detected, but the frequencies varied significantly: SBV was detected in 78 apiaries, DWV in 55, ABPV in 11, CBPV in 4, BQCV in 1 and KBV in 1. This is the first record of KBV in Denmark. A large majority of the bee samples were infected with one or more viruses. Single, dual and triple infections were observed. Nucleotide sequences of the PCR products from each virus were determined and found to be $98-99 \%$ identical to GenBank accessions except CBPV, which was only $88-90 \%$ identical to known CBPV sequences.
\end{abstract}

Kashmir bee virus / acute bee paralysis virus / black queen cell virus / chronic bee paralysis virus / deformed wing virus / sacbrood virus / multiple virus infection

\section{INTRODUCTION}

In 1971 three viruses were known to infect honey-bees (Bailey, 1971), but five years later the number had increased to six (Bailey, 1976). Today about 15 viruses have been isolated from the honey bee Apis mellifera L. (Anderson, 1995; Allen and Ball, 1996). Only limited information on the occurrence of bee viruses in Apis mellifera in Denmark is available, as no comprehensive survey has been carried out. Acute bee paralysis virus (ABPV) has been noted as common (Brødsgaard and Hansen, 1996a; Nordström et al., 1999), while deformed wing virus (DWV) (Brødsgaard and Hansen, 1996b), cloudy wing virus (CWV), black queen cell virus (BQCV) and bee virus X (BVX) (Nordström et al., 1999), chronic

Corresponding author: S.L. Nielsen,

SteenL.Nielsen@agrsci.dk

* Manuscript editor: Stefan Fuchs bee paralysis virus (CBPV) (Hansen, 1992) and bee virus Y (BVY) (Allen and Ball, 1996) have been reported to occur in Denmark. However, for bee virus Y (BVY), Allen and Ball (1996) do not give references supporting its presence in Denmark. Based on information from Danish bee inspectors, symptoms of sacbrood virus (SBV) are quite common and the incidence appears to be increasing (unpubl. data).

According to Allen and Ball (1996) ABPV, SBV and CWV are often observed and are widespread in Europe. DWV is widespread, but it is seldom found, while information on BQCV and CBPV is limited. Data compiled by Allen and Ball (1996) was based on serology, electron microscopy and visual symptoms. Recent surveys using nucleic acid-based diagnostics have given a more detailed picture. Siede and Büchler (2003) made a survey of ABPV, BQCV, CBPV, KBV and SBV 
in the Hessen region in Germany and recorded three of the viruses: ABPV, BQCV and SBV. Tencheva et al. (2004) studied the occurrence and distribution of six bee viruses in 36 apiaries in France, namely ABPV, BQCV, CBPV, DWV, KBV and SBV. In Europe, KBV has been recorded in Spain (Allen and Ball, 1995), France (Tencheva et al., 2004), Germany (Siede and Büchler, 2004), Luxemburg (Siede et al., 2005) and the United Kingdom (Ward et al., 2007). KBV is the most virulent of all known honey bee viruses (Bailey and Woods, 1977; Allen and Ball, 1995).

A survey based on the RT-PCR methods published by Tentcheva et al. (2004) (ABPV, BQCV, CBPV, DWV, KBV) and Grabensteiner et al. (2001) (SBV) was carried out in Denmark, as these viruses probably are the most important in Europe. The present survey is based on honey bee samples from apiaries with unusually high winter mortality or other suspicion of virus disease.

The mite Varroa destructor (Oudemans) is associated with spread of some bee viruses. $V$ destructor was first recorded in Denmark in 1984, but only became widespread in the 1990's (Brødsgaard et al., 1996a).

\section{MATERIALS AND METHODS}

\subsection{Bee samples}

Samples of adult bees or brood from apiaries with unusually high mortality during winter, or from hives with other suspicion of disease outbreak were provided by Danish beekeepers. Samples from the Department of Integrated Pest Management (University of Aarhus)'s own bee hives were included. All samples could be referred to geographic locality. All samples were stored at $-20{ }^{\circ} \mathrm{C}$ before RNA extraction. Honey bees known to be infected with ABPV, BQCV, CBPV, DWV, KBV and SBV were kindly provided by Dr. L. Gauthier from University Montpellier II (France).

\subsection{Sample preparation, RNA extraction and RT-PCR analysis}

Single bees or larvae were crushed in a mortar or in a microtube with liquid nitrogen. Total RNA was purified using NucleoSpin RNA II kit (MachereyNagel, Düren, Germany) according to the manufacturer's instructions and stored at $-80^{\circ} \mathrm{C}$.

Synthesis of cDNA and PCR amplification was performed using a OneStep RT-PCR kit (QIAGEN, Hilden, Germany). Four $\mu \mathrm{L}$ template RNA were mixed with $10 \mu \mathrm{L} 5 \times$ OneStep RT-PCR buffer, $10 \mu \mathrm{L} 5 \times \mathrm{Q}$-solution, $2 \mu \mathrm{L}$ dNTP-mix, forward and reverse primers at a final concentration of $0.6 \mu \mathrm{M}$, $2 \mu \mathrm{L}$ OneStep RT-PCR enzyme mix and water to a final volume of $50 \mu \mathrm{L}$. The primer pairs used are shown in Table I.

The reaction was performed in a GeneAmp PCR System 9700 thermal cycler (PE Applied Biosystems, Foster City, USA) using the following thermal profile: $30 \mathrm{~min}$ at $50{ }^{\circ} \mathrm{C}$ and for $5 \mathrm{~min}$ at $94^{\circ} \mathrm{C}$ followed by 35 amplification cycles $\left(30 \mathrm{~s}\right.$ at $94^{\circ} \mathrm{C}$, $\mathrm{Y}$ s at $\mathrm{X}{ }^{\circ} \mathrm{C}, 60 \mathrm{~s}$ at $72{ }^{\circ} \mathrm{C}$ ) finishing with $7 \mathrm{~min}$ at $72{ }^{\circ} \mathrm{C}$. The factors $\mathrm{X}$ and $\mathrm{Y}$ were variable for the six viruses and are shown in Table I. The PCR products were analysed by electrophoresis in a $1.5 \%$ agarose gel. All samples were tested for the presence of all six viruses.

To confirm the identity of the PCR product, representative samples from the virus amplifications were sequenced (MWG-Biotech AG, Germany) and the sequences were blasted against the GenBank database.

\section{RESULTS}

In total, 96 apiaries were examined for the presence of six viruses (ABPV, BQCV, CBPV, DWV, KBV and SBV) using RT-PCR. All six viruses were detected, but the frequencies were highly different. SBV was detected in 78 apiaries, DWV in 55, ABPV in 11, CBPV in 4 and BQCV and KBV in one apiary each. A large majority of the bee samples were infected with more than one virus. The number and combinations of multiple infections detected are shown in Table II. The results show that multiple infections are commonly observed. Thirty-nine of the samples were infected with both DWV and SBV. Two other dual and four triple infection combinations were recorded. For DWV, multiple infections were recorded in 52 out of 55 total records and for SBV the results were 41 multiple infections out of 78 records.

The nucleotide sequences of PCR products from the six viruses were determined 
Table I. The primers and the amplification cycles used for the RT-PCR analysis of six honey bee viruses. (All primers: Tentcheva et al., 2004 except SBV: Grabensteiner et al., 2001).

\begin{tabular}{|c|c|c|c|}
\hline Virus & Primers (5'-3') & $\begin{array}{l}\text { Product } \\
\text { length bp }\end{array}$ & $\begin{array}{l}\text { Parameters for the } \\
\text { RT-PCR program of } \\
\text { the thermal cycler* }\end{array}$ \\
\hline ABPV & $\begin{array}{l}\text { TGAGAACACCTGTAATGTGG } \\
\text { ACCAGAGGGTTGACTGTGTG }\end{array}$ & 452 & $\mathrm{X}=56^{\circ} \mathrm{C}, \mathrm{Y}=45 \mathrm{~s}$ \\
\hline BQCV & $\begin{array}{l}\text { GGACGAAAGGAAGCCTAA AC } \\
\text { ACTAGGAAGAGACTTGCACC }\end{array}$ & 424 & $\mathrm{X}=60^{\circ} \mathrm{C}, \mathrm{Y}=30 \mathrm{~s}$ \\
\hline CBPV & $\begin{array}{l}\text { AGTTGTCATGGTTAACAGGATACGAG } \\
\text { TCTAATCTTAGCACGAAAGCCGAG }\end{array}$ & 455 & $\mathrm{X}=60^{\circ} \mathrm{C}, \mathrm{Y}=30 \mathrm{~s}$ \\
\hline DWV & $\begin{array}{l}\text { TTTGCAAGATGCTGTATGTGG } \\
\text { GTCGTGCAGCTCGATAGGAT }\end{array}$ & 395 & $\mathrm{X}=56^{\circ} \mathrm{C}, \mathrm{Y}=45 \mathrm{~s}$ \\
\hline KBV & $\begin{array}{l}\text { GATGAACGTCGACCTATTGA } \\
\text { TGTGGGTTGGCTATGAGTCA }\end{array}$ & 393 & $\mathrm{X}=56^{\circ} \mathrm{C}, \mathrm{Y}=45 \mathrm{~s}$ \\
\hline SBV & $\begin{array}{l}\text { ACCACCCGATTCCTCAGTAG } \\
\text { CCTTGGAACTCTGCTGTGTA }\end{array}$ & 487 & $\mathrm{X}=56^{\circ} \mathrm{C}, \mathrm{Y}=45 \mathrm{~s}$ \\
\hline
\end{tabular}

* The general RT-PCR program of the thermal cycler is $50{ }^{\circ} \mathrm{C} / 30 \mathrm{~min}, 94{ }^{\circ} \mathrm{C} / 5 \mathrm{~min},\left(94{ }^{\circ} \mathrm{C} / 30 \mathrm{~s}, \mathrm{X}{ }^{\circ} \mathrm{C} / \mathrm{Y} \mathrm{s}\right.$, $\left.72{ }^{\circ} \mathrm{C} / 60 \mathrm{~s}\right) \times 35$ cycles, $72{ }^{\circ} \mathrm{C} / 7 \mathrm{~min}$.

Table II. The numbers of single and multiple virus infections and the combinations of multiple virus infections. ABPV: Acute bee paralysis virus, BQCV: black queen cell virus, CBPV: chronic bee paralysis virus, DWV: deformed wing virus, KBV: Kashmir bee virus, SBV: sacbrood virus.

\begin{tabular}{lc}
\hline Virus combination & Number of samples \\
\hline Single infection & 27 \\
SBV & 3 \\
DWV & 1 \\
ABPV & 1 \\
CBPV & \\
Dual infections & 39 \\
DWV + SBV & 1 \\
DWV + ABPV & 1 \\
SBV + ABPV & \\
Triple infections & 7 \\
DWV + ABPV + SBV & 3 \\
DWV + CBPV + SBV & 1 \\
DWV + BQCV + SBV & 1 \\
DWV + ABPV + KBV & \\
\hline
\end{tabular}

and Blast searches in GenBank confirmed the identity of the viruses. The nucleotide sequences of the PCR products of ABPV (acc. No. EF570888), DWV (acc. No. EF570890), KBV (acc. No. EF570891), and SBV (acc. No. EF570887) were 98-99\% identical to sequences in the Genbank. The identity for CBPV (acc. No. EF570889) was only 86-88\% compared to CBPV sequences in GenBank whereas the translated hypothetical polypeptide from the PCR product showed 97-99\% identity to the CBPV RNA polymerase. Unfortunately, only limited sequence information was obtained for BQCV (not submitted to GenBank), however a $90 \%$ hit was found to a BQCV sequence in GenBank, thus verifying the identity of the PCR product.

\section{DISCUSSION}

BLAST searches confirmed that the six PCR assays all resulted in a virus-specific product. All six viruses were detected in Danish apiaries. However, the incidence of the six viruses in Denmark differed very much from the ones found in France, where DWV was recorded in $97 \%, \mathrm{SBV}$ in $86 \%$, BQCV in $86 \%$, ABPV in $58 \%$, CBPV in $28 \%$ and $\mathrm{KBV}$ in $17 \%$ of apiaries (Tencheva et al., 2004). The record of KBV is new for Denmark. The low frequency of ABPV in Denmark $(14 \%)$ is remarkable, not only compared to the French result, but also compared to results from Hessen, Germany, where Siede and Büchler (2003) recorded ABPV in 57\% of the apiaries. It also contrasts with the statement of Allen and Ball (1996) that ABPV was very common and widespread in Europe. The reason for the scarcity of ABPV, compared to 
previous studies of Danish bees (Brødsgaard and Hansen, 1996a), may reflect different control strategies directed against $V$. destructor. Most Danish beekeepers use organic acids, and their bees have to cope with slightly higher numbers of mites. Therefore, bees susceptible to ABPV may have been selected against for the past decade, and due to frequent occurrence of these mites, may have disappeared, as predicted by Martin (2001). The low incidence of CBPV and BQCV in Denmark deviate from the French results. Three of the four findings of CBPV in Denmark were on the Island of Læs $\varnothing$, on bees identified as Apis mellifera mellifera. Out of totally 583 bee colonies of either A. mellifera mellifera or A. mellifera ligustica that were inspected visually, symptoms of CBPV were seen only on A. mellifera mellifera. This subspecies, indigenous to Western Europe, is now rare in the rest of Denmark. In France, where A. m. mellifera is common, frequent occurrence of CBPV is recorded (Tentcheva et al., 2004; Gauthier et al., 2007). However, no results on differences in susceptibility to CBPV between the various subspecies have been published. Interestingly, the nucleotide sequence of the PCR product of these Danish isolates were only $88 \%$ identical to French CBPV sequences. $\mathrm{KBV}$ was found in one honey bee, which was simultaneously infected with ABPV and DWV. This new record of KBV adds to the records of its occurrence in five other European countries. A closer look on the history of the KBV infected apiary did not reveal any clue of the origin.

A high incidence of dual and triple infections was observed. In fact, multiple infections were more common than single infections. Multiple virus infections have been recorded by others. Anderson and Gibbs (1988) found indication of multiple infections with BQCV, KBV and SBV. Evans (2001) and Topley et al. (2005) reported dual-infection with ABPV and $\mathrm{KBV}$ and with BQCV and SBV, respectively. Siede and Büchler (2003) reported dual and triple infections with ABPV, BQCV and SBV. Chen et al. (2004) reported mixed infection with SBV and DWV and also triple and quadruple infection with KBV, DWV, SBV and BQCV.

\section{ACKNOWLEDGEMENTS}

We gratefully acknowledge Dr. Laurent Gauthier from University Montpellier II, who kindly provided virus infected bee material. We thank Danish beekeepers and bee inspectors, who sent diseased honey bees. The study was financed by the EC honey programme 2004-07 and by University of Aarhus, Faculty of Agricultural Science.

Fréquence au Danemark du virus de la paralysie aiguë de l'abeille (ABPV), du virus de la cellule noire de reine (BQCV), du virus de la paralysie chronique de l'abeille (CBPV), du virus des ailes déformées (DWV), du virus du Cachemire de l'abeille (KBV) et du virus du couvain sacciforme (SBV) chez l'abeille domestique (Apis mellifera).

\section{infection virale multiple}

Zusammenfassung - Auftreten vom AkuteBienenparalyse-Virus, Schwarze-Königinnenzellen-Virus, Chronische-Bienenparalyse-Virus, Verkrüppelte-Flügel-Virus, Kaschmir-BienenVirus und Sackbrut-Virus bei Honigbienen (Apis mellifera L.) in Dänemark. Neuere Untersuchungen zur Verbreitung von Bienenviren unter Verwendung molekulargenetischer Diagnosemethoden wurden in Europa lediglich in Frankreich und Deutschland durchgeführt. Um auch für Dänemark einen detaillierten Überblick $\mathrm{zu}$ erhalten, wurden adulte Honigbienen von Bienenständen mit außergewöhnlich hoher Wintermortalität sowie Brutwaben von Bienenvölkern mit Krankheitssymptomen mittels RT-PCR auf folgende Viruserkrankungen hin untersucht: Akute-Bienenparalyse-Virus (ABPV), SchwarzeKöniginnenzellen-Virus (BQCV), KaschmirBienen-Virus (KBV), Chronische-BienenparalyseVirus (CBPV), Verkrüppelte-Flügel-Virus (DWV) und Sackbrut-Virus (SBV). Die verwendeten Primer und RT-PCR-Verfahren wurden der Literatur entnommen. Alle Proben wurden auf das Vorkommen aller sechs Bienenviren hin analysiert. Um die PCR-Produkte eindeutig zu identifizieren, wurden repräsentative Proben sequenziert und die Sequenzen gegen die GenBank-Datenbank geblasted.

Insgesamt wurden 96 Bienenstände auf das Vorkommen der sechs Bienenviren hin untersucht. Alle sechs Viren wurden nachgewiesen, allerdings in sehr unterschiedlicher Häufigkeit. SBV wurde in $78, \mathrm{DWV}$ in $55, \mathrm{ABPV}$ in $11, \mathrm{CBPV}$ in 4 und BQCV sowie KBV in einem Bienenstand festgestellt. Die Mehrzahl der Bienenproben war von mehr als einem Bienenvirus befallen, wobei Einzel-, Doppel- und Tripelbefall vorkamen. 
Die Nukleotidsequenzen der PCR-Produkte aller Viren waren zu 98-99\% identisch mit den GenBank-Sequenzen mit Ausnahme von CBPV, der lediglich eine Übereinstimmung von $88-90 \%$ zu den bekannten CBPV-Sequenzen aufwies. Die Häufigkeit der sechs Bienenviren in Dänemark unterscheidet sich erheblich von den Ergebnissen aus anderen europäischen Ländern. Im Gegensatz zu diesen Ländern war SBV am meisten verbreitet, gefolgt von DWV. Außerdem war die Häufigkeit von ABPV, BQCV und CBPV deutlich geringer als sonst beschrieben. KBV wurde erstmals in Dänemark nachgewiesen und erweitert die bisherigen Funde von KBV aus fünf anderen europäischen Ländern.

Kaschmir-Bienen-Virus / Akute-Bienenparalyse -Virus / Schwarze-Königinnenzellen-Virus / Chronische-Bienenparalyse-Virus / Verkrüppelte-Flügel-Virus / Sackbrut-Virus / VirusMehrfachinfektion

\section{REFERENCES}

Allen M., Ball B. (1995) Characterisation and serological relationships of strains of Kashmir bee virus, Ann. Appl. Biol. 126, 471-484.

Allen M., Ball B. (1996) The incidence and world of honey bee viruses, Bee World 77, 141-162.

Anderson D.L. (1995) Viruses of Apis cerana and Apis mellifera, in: Kevan P.G. (Ed.), The Asiatic hive bee: apiculture, biology, and role in sustainable development in tropical and subtropical Asia, Enviroquest Ltd., Cambridge, pp. 161-170.

Anderson D.L., Gibbs A.J. (1988) Inapparent virus infections and their interactions in pupae of the honey bee (Apis mellifera Linnaeus) in Australia, J. Gen. Virol. 69, 1617-1625.

Bailey L. (1971) Honey-bee viruses, Science Progress, Oxford 59, 309-323.

Bailey L. (1976) Viruses attacking the honey bee, Adv. Virus Res. 20, 271-304.

Bailey L., Woods R.D. (1977) Two small RNA viruses from honey bees and further observations on sacbrood and acute bee-paralysis viruses, J. Gen. Virol. 37, 175-182.

Brødsgaard C.J., Hansen H. (1996a) Virus og varroa - en dødelig kombination [Virus and varroa - a deadly combination], Grøn Viden Landbrug 162, $4 \mathrm{p}$.

Brødsgaard C.J., Hansen, H. (1996b) Deformeret vingevirus - også et problem $\mathrm{i}$ forbindelse med varroa. [Deformed wing virus - also a problem in combination with varroa], Tidsskrift for Biavl 2/96, 49 .
Chen Y., Zhao Y., Hammond J., Hsu H.-T., Evans J., Feldlaufer M. (2004) Multiple virus infections in the honey bee and genome divergence of honey bee viruses, J. Invertebr. Pathol. 87, 84-93.

Evans J.D. (2001) Genetic evidence for coinfection of honey bees by acute bee paralysis and Kashmir bee viruses, J. Invertebr. Pathol. 78, 189-193.

Gauthier L., Tentcheva D., Tournaire M., Dainat B., Cousserans F., Colin M.E., Bergoin M. (2007) Viral load estimation in asymptomatic honey bee colonies using the quantitative RT-PCR technique, Apidologie 38, 426-435.

Grabensteiner E., Ritter W., Carter M.J., Davidson S., Pechhacker H., Kolodziejek J., Boecking O., Derakhshifar I., Moosbeskhofer R. (2001) Sacbrood virus of the honey bee (Apis mellifera): rapid identification and phylogenetic analysis using reverse transcription-PCR., Clin. Diagn. Lab. Immunol. 8, 93-104.

Hansen H. (1992) Sygdomme og parasitter hos voksne honningbier. [Diseases and parasites of imagines of honey bees] Biavlernes Etiketkontor ved L. Launsø. ISBN 87-87905 388, 16 p.

Martin S.J. (2001) The role of Varroa and viral pathogenes in the collapse of honey bee colonies: a modelling approach, J. Appl. Ecol. 38, 10821093.

Nordström S., Fries I., Aarhus A., Hansen H., Korpela S. (1999) Virus infections in Nordic honey bee colonies with no, low or severe Varroa jacobsoni infestation, Apidologie 30, 475-484.

Siede R., Büchler R. (2003) Viren der Honigbiene. Verbreitung und Einflussgrössen der Virosen in Hessen, Allg. Dtsch. Imkerztg 3/2003, 26-28.

Siede R., Büchler R. (2004) First detection of Kashmir bee virus in Hesse, Germany, Berl. Münch. Tierarztl. Wochenschr. 117, 12-15.

Siede R., Derakhshifar I., Otten C., Berényi O., Bakonyi T., Köglberger H., Büchler R. (2005) Prevalence of Kashmir bee virus in central Europe, J. Bee Res. 44, 129.

Tentcheva D., Gauthier L., Zappulla N., Dainat B., Cousserans F., Colin M.E., Bergoin M. (2004) Prevalence and seasonal variations of six bee viruses in Apis mellifera L. and Varroa destructor mite populations in France, Appl. Environ. Microbiol. 70, 7185-7191.

Topley E., Davison S., Leat N., Benjeddou, M. (2005) Detection of three honey bee viruses simultaneously by a single multiplex reverse transcriptase PCR, Afr. J. Biotechnol. 4, 763-767.

Ward L., Waite R., Boonham N., Fisher T., Pescod K., Thompson H., Chantawannakul P., Brown M. (2007) First detection of Kashmir bee virus in the UK using real-time PCR, Apidologie 38, 181190. 